\title{
Notes on Bryum medianum Mitt. (Bryaceae) collected from Tsum Valley, central Nepal
}

\author{
J. P. Gajurel ${ }^{2, *}$, S. K. Rai ${ }^{1,4}$, N. Pradhan ${ }^{3}$ and C. Scheidegger ${ }^{4}$
}

Bryophytes are very important parts of ecosystem however their study is done less as compared to vascular plants in Nepal. There are 766 taxa of mosses in Nepal (Pradhan 2000, 2006). The genus Bryum Hedw. Represents the taxon of Bryaceae (Bryophyta). Bryum medianum Mitt. has been reported from Meghalaya, from Khasia hills (Gangulee 1969-1980) as well as Thailand and Malayasia. However, the specimen of this species has not been deposited in Nepal (Pradhan $2000,2006)$; is a new addition to the specimens of bryoflora in Natural History Museum, Nepal when compared with other specis of the same genus in the $=$ Natural History Museum, Nepal.

The study sites was Tsum valley located in Manaslu Conservation Area of Gorkha District. The species was observed during the biodiversity assessment. This species was recorded from Natural forest of Pinus wallichiana, Quercus semicarpifolia, Rhododendron arboreum, Rubus peniculatus, Hedera nepalensis, Thallictrum reniforme, etc were associated in the site.

The locality of this species consisted of moist environment with ca $10 \mathrm{~cm}$ litter deposition at the time of collection of the specimen. The species was photographed. It was then put in envelop and pressed along with other angiosperm. The specimen was dried and identified in the lab of Natural History Museum, Nepal. In this short note, the taxonomy based on the specimen of the species has been described.

\section{Taxonomy}

Bryum medianum Mitt. J. Proc. Linn. Soc., Bot., Suppl. 1: 741859.

Plants small, closely tufted, bright green, reddish brown when dry. Rhizoids are reddish brown. Shoots erect, 4-4.5 cm long. Stems slender, short, branched. Leaves numerous, more crowded in the lower part of stem, erect, 1.5-2 × $1-1.2$ $\mathrm{mm}$, oblong-lanceolate, sharply acuminate; margins entire, with distinct mid-vein. Seta erect, 3-7 cm long, dark reddish- brown. Capsule thick, cylindrical, $2-3 \mathrm{~mm}$; operculum conical; peristome well developed (Fig.1).

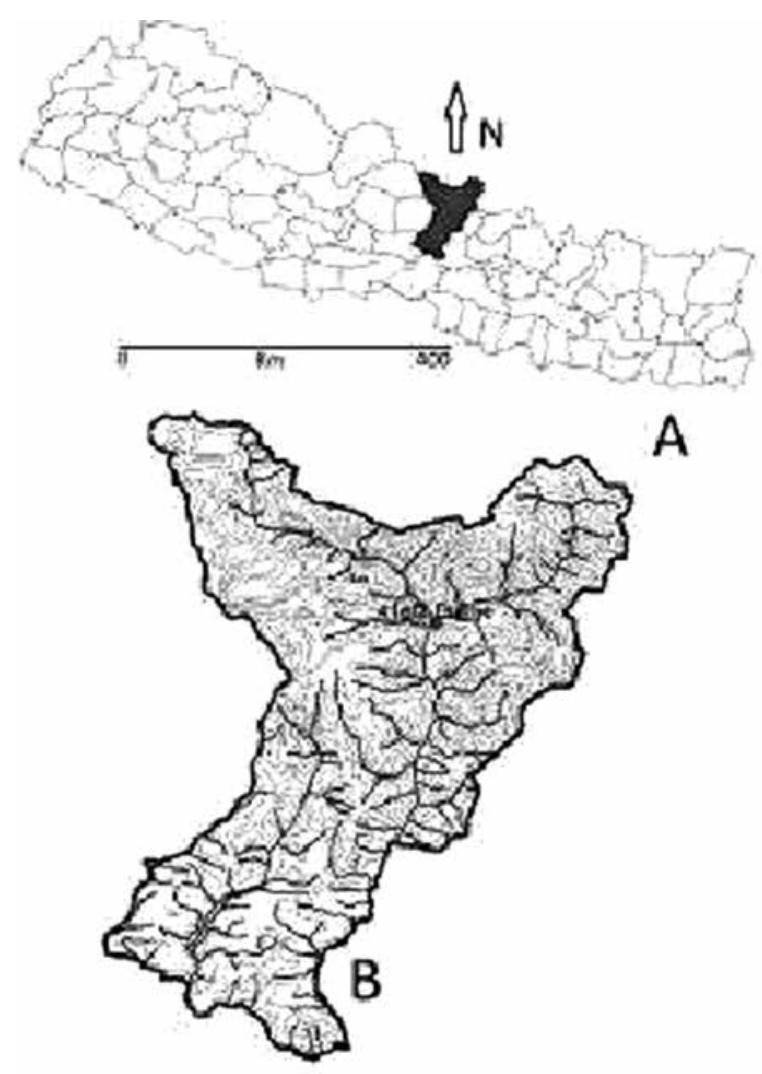

Fig. 1: Collection site: A Map of Nepal; B Gorkha District and locality

Specimen examined: Central Nepal, Gandaki Zone, Gorkha district, Above Dumje, opposite to the trail to Chum valley, $2600 \mathrm{~m}, 12$ September

\footnotetext{
1 Department of Plant Resources, Ministry of Forests and Soil Conservation, Government of Nepal. *E-mail:jpgajurel2010@gmail.com

2 Tribhuvan University, Central Department of Botany, Kirtipur, Kathmandu, Nepal.

3 Natural History Museum, Tribhuvan University, Swayambhu, Kathmandu, Nepal

4 Swiss Federal Institute for Forest, Snow and Landscape Research, WSL
} 
2012, J. P. Gajurel, S. K. Rai, Bibas Rai \& Bhim Rai, Coll No: BRY 37a (Natural History Museum).

Distribution: Central Nepal (Dumje, Tsum valley, Gorkha District,Fig. 2), South India, Thailand, Malayasia.
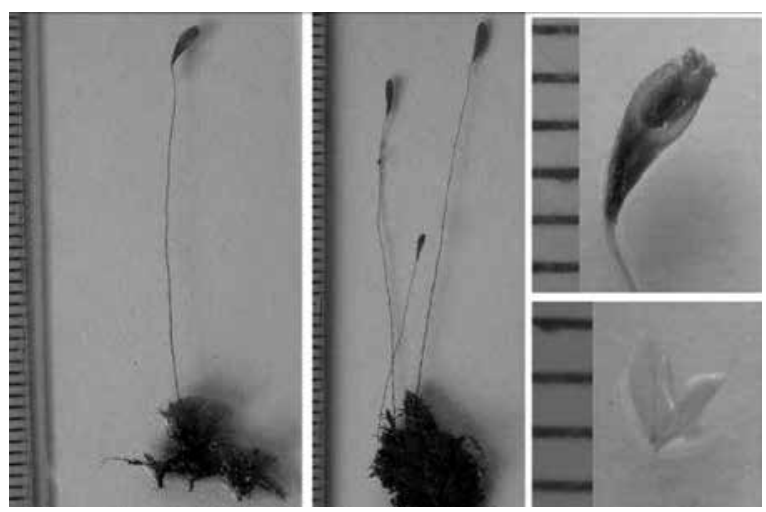

Fig. 2: Habit; A Entire Plant (moist); B Entire Plant (Dry); C. Capsule; D Leaf; the scale on margin represent $\mathrm{mm}$.

\section{Discussion}

Bryophytes are less studied in Nepal as compared to higher plants. There are 766 taxa of mosses in Nepal (Pradhan 2000, 2006) which do not include Bryum medianum Mitt. This species have been collected and preserved in India, Thailand and Malayasia (Frahm et al. 2013; Gangulee 19691980). The potential distribution of this species was reported by Gangulee (1969-1980) in Nepal; however, there are no records on the specimen collected or deposited in Nepal. The present study, confirms his distribution range. This note on the Bryum medianum Mitt. concludes the new addition to bryoflora to Nepal and make contribution to existing checklist of bryoflora. As the number of specimens were localized in small area, it further recommends for conservation of the species in the natural habitat in Tsum valley.

\section{Acknowledgement}

We are grateful to Krishna Kumar Shrestha (former head, the Central Department of Botany, Tribhuvan University) for coordinating the project in Nepal. We are also thankful to the Swiss National Science Foundation (grant JRP IZ70Z0_131338/1 to Christoph Scheidegger), Central Department of Botany, Tribhuvan University, Nepal for providing logistics to the field trip. We are thankful to Mr. Shiva Devkota, $\mathrm{PhD}$ Scholar of Bern University, Switzerland and to the staff of KATH and Wilderplaces Treks, Kathmandu, for their cooperation.

\section{References}

Frahm, J.P., Schwarz, U. \& Manju, C.N. 2013. A checklist of the mosses of Karnataka, India. Archive for Bryology 158 : 2-15.

Gangulee, H.C. 1969-1980. Mosses of Eastern India and Adjacent Regions. Vols. I-III, (Fasc. 1-8), BSI, Calcutta.

Pradhan, N. 2000. Materials for a Checklist of Bryophytes of Nepal. British Museum, London. UK.

Pradhan, N. and Joshi, S.D. 2006. A Checklist of Fissidens species (Musci: Fissidentaceae) of Nepal. Our Nature 4 : 61-68. 